\title{
PEMBENTUKAN PELESAPAN DALAM KALIMAT BAHASA SUNDA LISAN DI PASAR PADAYUNGAN KOTA TASIKMALAYA (Pendekatan Tata Bahasa Transformasi)
}

\author{
Ai Paridah, Yayat Sudaryat, Usep Kuswari \\ MA Al-Amin Kota Tasikmalaya \\ Pos-el: aiparidah@gmail.com, yayat.sudaryat@upi.edu, usep.kuswari@upi.edu
}

\begin{abstract}
Abstrak
Penelitian ini bertujuan untuk menganalisis serta mendeskripsikan unsur-unsur fungsional klausa yang mengalami pelesapan dengan menggunakan pendekatan transformasi kalimat yang terdapat dalam interaksi di pasar Padayungan Kota Tasikmalaya. Dalam penelitian ini digunakan metode deskriptif, tehnik yang digunakan dalam penelitian ini yaitu menggunakan tehnik sadap rékam. Pengolahan data menggunakan analisis teks. Sumber data adalah percakapan atau interaksi di pasar Padayungan kota Tasikmalaya. Seluruh transformasi kalimat dan pelesapan unsur-unsur fungsional klausa dijadikan populasi atau sampel total. Ragam bahasa Sunda lisan didukung oleh situasi pemakaian sehingga kemungkinan besar terjadi pelesapan kalimat. Namun, hal itu tidak mengurangi ciri kebakuannya. Walaupun demikian, ketepatan dalam pilihan kata dan bentuk kata serta kelengkapan unsur-unsur di dalam struktur kalimat tidak menjadi ciri kebakuan dalam ragam baku lisan karena situasi dan kondisi pembicaraan menjadi pendukung di dalam memahami makna gagasan yang disampaikan secara lisan.Transformasi ialah proses pembentukan unsur bahasa dari struktur dasar ke struktur turunan. Dalam transformasi, terdapat pelesapan atau yang disebut elipsis. Kalimat elipsis adalah kalimat tidak sempurna yang terjadi karena penghilangan bebrapa bagian dari klausa, dan diturunkan dari kalimat tunggal. Melalui penelitian ini, maka anggapan tentang pelesapan dalam bentuk bahasa Sunda lisan di masarakat pasar Padayungan kota Tasikmalaya, terbukti benar adanya.
\end{abstract}

Kata kunci: pelesapan, bahasa Sunda lisan, tata bahasa transformasi

\section{FORMING ELLIPSION ON SUNDANESE VERBAL SENTENCES AT PADAYUNGAN MARKET CITY OF TASIKMALAYA (A Tranformation Grammar Approach)}

\begin{abstract}
This research aims to describe and analyze elements of clausal functionsthat undergo elision by using a transformation approach on sentences from communal interactions at Padayungan Market, Tasikmalaya City. This research adopted a descriptive method by way of a tapping record to gather data. Data from communal interactions and conversations at Padayungan Market, Tasikmalaya were analyzed by a textual analysis. The entire sentential transformation and deletion of clausal functions were treated as population or total sampling. Oral language relies on its contexts of use; therefore, ellipsion occurs. Such, however, does not undermine grammaticality.
\end{abstract}


Nevertheless, accuracy in word choice and word form is not characteristic of oral register since the contexts of utterance assist in understanding the meaning. Transformation is a process of constructinglanguage features from underlying structure to derivative structure. In transformation, there is deletion or also known as ellipsis. Elliptical sentencesare incomplete sentences because of elimination of several clausal parts, derived from a single sentence. This research proves that ellipsis occurs in Sundanese oral register at Padayungan Market, Tasikmalaya.

Keywords: ellipsis, Sundanese oral language, transformation grammar

\section{PENDAHULUAN}

Ragam lisan adalah bahasa yang diujarkan oleh pemakai bahasa. Kita dapat menemukan ragam lisan yang standar, misalnya pada saat orang berpidato atau memberi sambutan, dalam situasi perkuliahan, ceramah; dan ragam lisan yang nonstandar, misalnya dalam percakapan antarteman, di pasar, atau dalam kesempatan nonformal lainnya.

Ragam bahasa baku lisan didukung oleh situasi pemakaian sehingga kemungkinan besar terjadi pelesapan kalimat. Namun, hal itu tidak mengurangi ciri kebakuannya. Walaupun demikian, ketepatan dalam pilihan kata dan bentuk kata serta kelengkapan unsurunsur di dalam struktur kalimat tidak menjadi ciri kebakuan dalam ragam baku lisan karena situasi dan kondisi pembicaraan menjadi pendukung di dalam memahami makna gagasan yang disampaikan secara lisan. Tetapi yang difokuskan dalam penelitian ini adalah pelesapan yang terjadi dalam ragam bahasa lisan hususnya dalam interaksi yang terjadi di pasar Padayungan dengan menggunakan pendekatan transformasi kalimat.

Transformasi ialah proses pembentukan unsur bahasa dari struktur dasar ke struktur turunan. Untuk dapat mengadakan suatu transformasi, maka perlu pertama-tama diketahui struktur kalimat dasar. Jika kita mengalihkan satu kalimat aktif ke dalam kalimat pasif, perlu kita ketahui struktur kalimat aktif itu, mana unsur-unsur nomina partikel dan verba partikel pada kalimat itu, mana yang masuk unsur nomina pertikel, mana yang masuk verba partikel, dan sebagainya. Samsuri (1985:221) membagi transformasi dalam lima jenis yaitu 1) transformasi tunggal, 2) transformasi sematan (seselan), 3) transformasi rapatan (kantetan), 4) transformasi fokus (puseur), dan 5) transformasi khusus.

\section{METODE}

Dalam penelitian ini digunakan metode deskriptif, tehnik yang digunakan dalam penelitian ini yaitu menggunakan tehnik sadap rékam. Pengolahan data menggunakan analisis teks. Sumber data adalah percakapan atau interaksi di pasar Padayungan kota Tasikmalaya. Seluruh transformasi kalimat dan pelesapan unsur-unsur fungsional klausa dijadikan populasi atau sampel total.

\section{HASIL DAN PEMBAHASAN}

Sebagaimana yang diungkapkan pada pendahuluan, transformasi tunggal bertolak dari sebuah kalimat (dasar), sedangkan transformasi sematan dan rapatan bertolak dari dua buah kalimat (dasar). Transformasi fokus memindahkan unsur-unsur yang difokuskan ke bagian lain dalam kalimat, pada umumnya ke bagian depan, sedangkan transformasi khusus, seperti yang dinyatakan oleh namanya, merupakan pembentukan kalimat-kalimat turunan secara khusus.

\section{Transformasi Tunggal}

1) Ingkar

Transformasi tunggal penambah ingkar dibagi lagi menjadi dua macam, yaitu pengingkaran terhadap frasa nomina dan pengingkaran terhadap pemadu yang lain. Untuk yang pertama, proses inimenambahkan 
pemadu bukan (lain), sedangkan untuk yang kedua transformasi ini menambahkan pemadu tidak (henteu). Kaidah transformasi ingkar mestilah menjelaskan bagian apa yang diingkari, sehingga pemadu yang ditambahkan dapat ditentukan apakah kata bukan atau kata tidak, termasuk pula tempat kata itu dalam kalimat turunannya. Dari 697 data transformasi tunggal yang terkumpul ditemukan 91 data kalimat transformasi tunggal penambah ingkar. Jadi hasil persentasinya adalah 13,06\%. Transformasi tunggal penambahan ingkar, bisa dilihat dari kalimat di bawah ini.

"Ah, wios ku éta gé lah, teu aya nu beureum Néng?” (KP2/015)

"Ah, biar yang itu juga, tidak ada yang merah, Néng?"

\section{2) Tanya I}

Tanya I yaitu kalimat tanya yang menanyakan salah satu pemadu dengan apa yang kami sebut kata ganti tanya, seperti $a p a$, siapa, mengapa, di mana, bilamana, bukan mana, dan berapa. Dari 697 data transformasi tunggal yang terkumpul ditemukan 117 data kalimat transformasi tunggal tanya I. Jadi hasil persentasinya adalah $16,79 \%$. Transformasi tunggal penambahan tanya I, bisa dilihat dari kalimat di bawah ini.

"Diopatkeun gé wios, sabaraha ayeuna?" (KD 2/074)

"Dibagi empat juga tidak apa-apa, berapa sekarang?"

\section{3) Seruan}

Dalam mengungkapkan pikiran melalui kalimat-kalimat pemakai bahasa sering pula menyisipkan ungkapan perasaan yang sukar dielakkan karena bahasa memang tidak saja merupakan alat menyatakan penalaran, melainkan juga emosi. Katakata yang pemakaiannya menyarankan emosi, yang biasa diletakkan saja pada kalimat yang dinyatakannya ialah kata seru, yang pemakaiannya menyebabkan timbulnya kalimat-kalimat yang disebut kalimat seru. Dari 697 data transformasi tunggal yang terkumpul, ditemukan 61 data kalimat transformasi tunggal seru. Jadi hasil persentasinya adalah $8,75 \%$. Transformasi tunggal seruan, bisa dilihat dari kalimat di bawah ini.

"Ah, wios ku éta gé lah, teu aya nu beureum Néng?" (KP2/015)

"Ah, biar yang itu juga, tidak ada yang merah, Néng?"

\section{4) Aspek}

Aspek atau partikel yang menunjukan perisiwa, keadaan, atau hal yang dimaksudkan oleh kalimat itu. Partikel aspek ditambahkan sebelum ulasan dasar, dan kecuali suasana seperti boleh, dapat, dan harus, tidak ada kata lain yang dapat berdiri di antara aspek dan ulasan dasar. Dari 697 data transformasi tunggal yang terkumpul, ditemukan 20 data kalimat transformasi tunggal aspek. Jadi hasil persentasinya adalah $2,87 \%$. Transformasi tunggal aspek, bisa dilihat dari kalimat di bawah ini.

"Ayeuna téh keur paciweuh, parebut." (KP2/071)

"Sekarang lagi sibuk, berebut."

5) Perintah

Perintah biasanya ditujukan kepada orang kedua di dalam percakapan maupun tulisan. Bahkan, banyak kalimat-kalimat berita biasa dengan pronominal kedua sebagai pokok (kalimat) dapat bersipat perintah. Dari 697 data transformasi tunggal yang terkumpul, ditemukan 40 data kalimat transformasi tunggal perintah. Jadi hasil persentasinya adalah 5,74\%. Transformasi tunggal perintah, bisa dilihat dari kalimat di bawah ini.

“Sok tingali heula ka dieu!” (KC 2/033)

"Silahkan lihat dulu ke sini!"

6) Kata Ganti

Kata ganti nomina atau pronomina hanya secara semiotik menggantikan orang ialah orang pertama atau pembicara dan 
orang kedua atau pendengar. Yang kedua ialah kelompok pronominal yang memang secara sintaktik menggantikan orang, yaitu pronominal ketiga yang menggantikan frasafrasa. Dari 697 data transformasi tunggal yang terkumpul, ditemukan 12 data kalimat transformasi tunggal perintah. Jadi hasil persentasinya adalah $1,72 \%$. Transformasi tunggal perintah, bisa dilihat dari kalimat di bawah ini.

"Ka abdi gé sarua ngabonan sakitu." (KD 2/016)

("Kepada saya juga sama ngambil segitu.")

\section{7) Tanya II}

Kalimat tanya II tidak jauh beda dengan kalimat tanya I, hanya saja yang membedakan yaitu kalimat tanya II tidak menggunakan kata-kata tanya seperti yang telah dijelaskan pada kalimat tanya I, seperti apa, di mana, bagaimana, berapa, dan bilamana. Dari 697 data transformasi tunggal yang terkumpul, ditemukan 155 data kalimat transformasi tunggal tanya II. Jadi hasil persentasinya adalah $22,24 \%$. Transformasi tunggal tanya II, bisa dilihat dari kalimat di bawah ini.

“Aya brosur bolu téa?" (KP 2/047)

"Ada brosur bolu?"

\section{8) Pemendekkan}

Mungkin karena pengaruh tulisan, kita menyangka bahwa kata-kata yang merupakan untai berstruktur, yaitu kalimat, diucapkan oleh pemakai bahasa satu per satu secara penuh. Hal itu tentu tidaklah demikian. Bergantung kepada kepentingan penekananannya, kata-kata dalam kalimat itu memperoleh pengucapan atau tidak. Namun, bagi kata-kata tertentu secara lisan dan mungkin juga tertulis, perwujudannya memang dengan sengaja dipendekkan atau mengalami kontraksi. Pemendekkan atau kontraksi itu disebabkan oleh karena katakata itu tidak ditekankan oleh pembicara sehingga dalam bahasa lisan tidak memperoleh pengucapan yang teliti dan akibatnya ialah kontraksi itu. Kontraksi itu lalu menjadi kebiasaan sehingga dalam bahasa tulisan pun akhirnya dipendekkan pula penulisannya. Dari 697 data transformasi tunggal yang terkumpul, ditemukan 201 data kalimat transformasi tunggal pemendekkan. Jadi hasil persentasinya adalah $28,83 \%$. Transformasi tunggal pemendekkan, bisa dilihat dari kalimat di bawah ini.

"Bu, bawang beureumna saons Bu?" (KS/134)

"Bu, bawang merahnya seons, Bu?"

\section{Transformasi Sematan}

Kaidah sematan $\mathrm{FN} \rightarrow \mathrm{FN}^{1}+\mathrm{K}$ dan $\mathrm{K} \rightarrow$ $\mathrm{FN}^{1}+$ Predikat, menunjukkan suatu proses yang menanamkan atau menyematkan sebuah kalimat (dasar) ke dalam kalimat (dasar) yang lain, yang dalam kaidah di atas itu hanya diwakili oleh $\mathrm{FN}^{1}$, dengan ketentuan bahwa subjek kalimat pemadu itu mesti identik dengan $\mathrm{FN}^{1}$ hasil sematan itu disebut kalimat sematan. Transformasi sematan biasanya ditandai dengan kata sekali dan sangat. Dari 1064 data transformasi kalimat yang terkumpul, ditemukan 3 data kalimat transformasi sematan. Jadi hasil persentasinya adalah $0,28 \%$. Transformasi sematan, bisa dilihat dari kalimat di bawah ini.

"Asa aya nu kandel pisan gé da." (KP/071)

"Kalau tidak salah ada yang tebal sekali."

\section{Transformasi Rapatan}

Kalimat rapatan yang merupakan hasil turunan dengan merapatkan kalimat yang satu ke kalimat yang lain. Misalnya kata-kata dan dan serta mempunyai makna "penambahan". Oleh karena itu, kata-kata itu disebut perapat penambahan atau perapat aditif, sedangkan kalimat turunan rapatan dengan perapat itu disebut kalimat penambahan atau kalimat aditif. Sudaryat, dkk. (2007:203) membagi kalimat rapatan dalam enam jenis. Dari keenam kalimat rapatan, hanya tiga jenis kalimat rapatan yang ditemukan, yaitu 
kalimat rapatan jumlah, kalimat rapatan berlawanan, dan kalimat rapatan kontinuatif. Dari 1064 data transformasi kalimat yang terkumpul, ditemukan 39 data kalimat transformasi rapatan. Jadi hasil persentasinya adalah 3,67\%. Dari 39 data kalimat, terdiri dari 31 data kalimat rapatan jumlah atau $79,49 \%$, 3 data kalimat berlawanan atau $7,69 \%$, dan 5 data kalimat kontinuatif atau $12,28 \%$.

Kalimat rapatan jumlah disebut juga kalimat ajungtif, yaitu kalimat rapatan yang mempunyai arti klausanya menunjukkan jumlah (Sudaryat, dkk., 2007: 203). Dari 39 data transformasi kalimat rapatan yang terkumpul, ditemukan 31 data kalimat transformasi rapatan. Jadi hasil persentasinya adalah 79,49\%. Transformasi rapatan jumlah, bisa dilihat dari kalimat di bawah ini.

"Dalapan meureun sareng anu tahuna wé opat, jadi dua belas, angsulna dalapan rébu." (KT/023)

"Mungkin delapan biji, dan tahunya empat saja, jadi dua belas, kembalian delapan ribu"

Kalimat rapatan berlawanan atau kalimat antitetik yaitu kalimat rapatan yang mempunyai arti antarklausa yang menunjukkan arti berlawanan (Sudaryat, dkk., 2007: 204). Dari 39 data transformasi kalimat rapatan yang terkumpul, ditemukan 3 data kalimat transformasi rapatan. Jadi hasil persentasinya adalah 7,69\%. Transformasi rapatan berlawanan, bisa dilihat dari kalimat di bawah ini.

"Di Nyi Ati mah dua rébu, tapi balocor." (KP 2/069)

"Di Nyi Ati harganya dua ribu, tapi bocor."

Kalimat rapatan kontinuatif kalimat yang mempunyai arti klausanya menunjukkan kejadian, kegiatan, atau proses yang dijelaskan dalam satu klausa, kemudian dijelaskan lagi dalam klausa yang lain (Sudaryat, dkk., 2007: 207).
Dari 39 data transformasi kalimat rapatan yang terkumpul, ditemukan 5 data kalimat transformasi rapatan kontinuatif. Jadi hasil persentasinya adalah $12,28 \%$. Transformasi rapatan kontinuatif, bisa dilihat dari kalimat di bawah ini.

"Teras tambihan naon deui, Néng?" (KK/031)

“Terus mau nambah apa lagi, Néng?"

\section{Transformasi Fokus}

Transformasi fokus ialah pemusatan perhatian pada salah satu unsur atau bagian kalimat oleh pembicara dan pendengar atau penulis dan pembaca yang dinyatakan oleh pembicara atau penulis dengan suatu bentukan kalimat tertentu. Dari 1064 data transformasi kalimat yang terkumpul, ditemukan 196 data kalimat transformasi fokus. Jadi hasil persentasinya adalah $18,42 \%$. Transformasi fokus, bisa dilihat dari kalimat di bawah ini.

"Dua kilo sapuluh rébu, janten genep belaseun.” (KC 2/076)

"Dua kilo sepuluh ribu, jadi enam belas."

\section{Transformasi Khusus}

Di samping transformasi fokus, masih terdapat sejumlah kalimat turunan yag tidak kami masukkan ke dalam kalimatkalimat turunan sebelumnya, yaitu kalimat sematan atau kalimat rapatan. Walaupun banyak turunan dalam bagian ini yang mempergunakan transformasi umum, yaitu proses yang didasarkan atas lebih dari sebuah kalimat (dasar), kami tidak memasukannya ke dalam transformasi umum karena sifat-sifat proses penurunannya berbeda dari sipat-sipat yang terdapat dalam transformasi umum. Kalimat-kalimat turunan yang termasuk dalam kelompok ini kami jadikan sebuah golongan, tidak karena mempunyai ciri-ciri konstruksi yang sama, melainkan masingmasing mempunyai ciri-cirinya sendiri. Jadi, dasar pengelompokannya hanya karena tidak dimasukkan ke dalam kelompok transformasi sebelumnya saja, sehingga karena itu 
bagian ini boleh disebut residu. Kita mulai pembicaraan mengenai transformasi khusus ini dengan yang sederhana. Transformasi khusus dibagi menjadi empat di antaranya yaitu penanda predikat, transformasi itu, transformasi nominalisasi, dan transformasi ada yang. Dari hasil penelitian, dari keempat data transformasi khusus yang ditemukan hanya dua kenis yang ditemukan yaitu transformasi khusus penanda predikat dan transformasi khusus nominalisasi.

\section{1) Transformasi Itu}

Kata itu mempunyai beberapa fungsi, yaitu sebagai penunjuk, sebagai penanda definitif, dan sebagai ganti anafora. Sebagai penunjuk kata itu dapat dan biasa dipertentangkan dengan kata ini. Sebagai penanda definitif biasa dipertentangkan dengan hal yang umum, atau tak tentu, yang dalam bahasa Indonesia dinyatakan tanpa penanda (unmarked). Kata itu sebagai kata ganti anafora yaitu menggantikan sebuah kata, sebuah frasa, atau bahkan seluruh kalimat. Dari 129 data transformasi khusus yang terkumpul, ditemukan 46 data kalimat transformasi khusus transformasi itu. Jadi hasil persentasinya adalah $35,66 \%$. Transformasi itu, bisa dilihat dari kalimat di bawah ini.

"Éta téh genep rébu dalapan ratus." (KK/022)

"Itu enam ribu delapan ratus."

\section{2) Transformasi Nominalisasi}

Transformasi nominalisasi merupakan proses penting bagi pembentukan nominal, yang dapat dibagi menjadi dua, yaitu nominalisasi dari kata dasar dan nominalisasi dari kalimat dasar. Dari 129 data transformasi khusus yang terkumpul, ditemukan 83 data kalimat transformasi khusus nominalisasi. Jadi hasil persentasinya adalah $64,34 \%$. Transformasi nominalisasi, bisa dilihat dari kalimat di bawah ini.

"Gulana anu bodas." (KP 1/006)

"Gulanya yang putih."

\section{Pelesapan}

Kalimat pelesapan atau disebut elipsis adalah kalimat tidak sempurna yang terjadi karena penghilangan bebrapa bagian dari klausa, dan diturunkan dari kalimat tunggal (Tarigan, 2009:48). Pelesapan atau ellipsis dalam kalimat, diberi tanda zero $(\varnothing)$.

\section{1) Subjek}

Subjek adalah bagian klausa yang berujud nomina atau frasa nominal yang dipakai untuk menandai apa yang dikatakan oleh penyapa. Di dalam klausa jalan teh leueur 'jalan itu licin', penyapa membicarakan ihwal jalan; bagian inilah yang lazim disebut subjek. Sebagai salah satu fungi sintaksis unsur klausa, subjek dipaparkan dengan memperhatikan masalah distribusi, wujud, kategori, dan peran semantis. Distribusi subjek adalah posisi yang diduduki oleh subjek. Ada dua posisi yang ditempati subjek, yaitu (1) posisi kiri predikat dan (2) posisi kanan predikat.

Subjek berposisi di kiri predikat dalam klausa atau kalimat dasar. Diagramnya sebagai berikut.

Klausa $\rightarrow$ Subjek - Predikat - (O/Pelengkap) - (Keterangan)

Subjek berposisi di kanan predikat. Diagramnya sebagai berikut.

Klausa $\rightarrow$ Predikat - (Objek/Pelengkap) Subjek - Keterangan

Selain posisi yang diduduki, subjek juga mempunyai wujud yaitu bisa berwujud kata, frasa, dan klausa. Subjek yang berwujud kata, bisa berbentuk kata dasar, kata imbuhan, kata ulang, dan kata majemuk. Subjek yang berwujud frasa pada umumnya bertipe frasa endosentris, baik berupa frasa atributif, frasa koordinatif, dan frasa apositif (Sudaryat, 2014:100).

Dari 600 data pelesapan yang terkumpul, ditemukan 300 data pelesapan subjek. Jadi 
hasil persentasinya adalah 50\%. Pelesapan subjek, bisa dilihat dari kalimat di bawah ini.

“Ø nu beureum, Néng!"

*[Ontanna] nu beureum, Néng!
Dari data kalimat di atas, unsur fungsional yang lesap yaitu subjek, dan mempunyai pola -Subjek + Kat. Diagram pohonnya sebagai berikut.

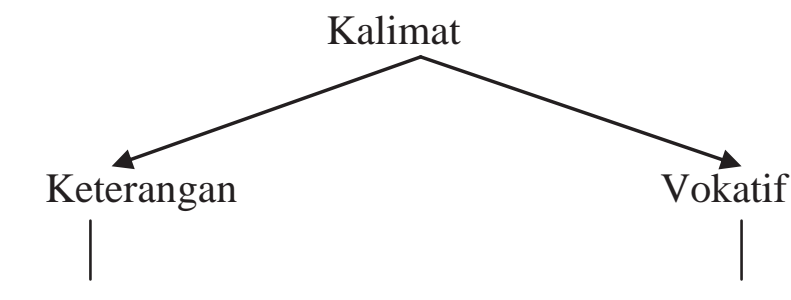

$\mathrm{Nu}$ beureum

Néng

Kalimat di atas, seupama dipulangkan, mempunyai diagram pohon sebagai berikut.

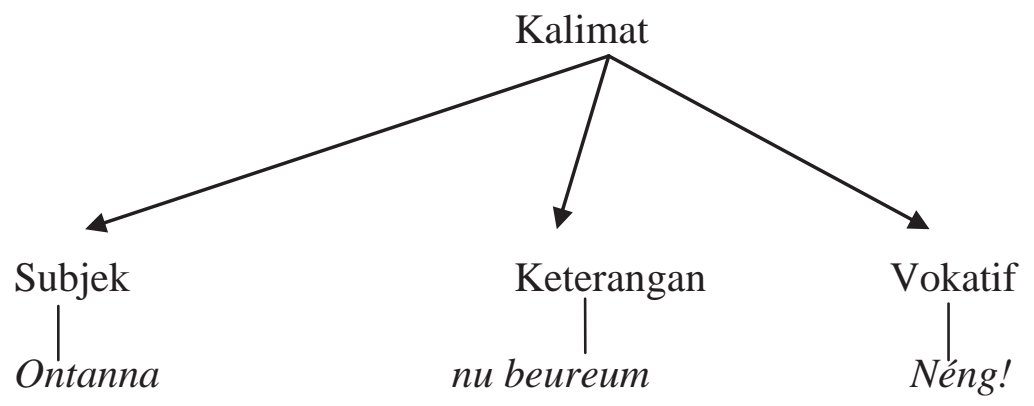

2) Predikat

Predikat adalah unsur klausa yang menandai apa yang dikatakan penyapa tentang subjek. Dalam klausa manéhna téh bangor 'dia itu nakal', penyapa mengatakan manéhna téh (subjek); tentang "manéhna téh" ia mengatakan bangor, bagian ini disebut predikat.

Distribusi predikat dalam bahasa Sunda memiliki dua posisi, yakni (1) di belakang subjek dan (2) di depan subjek. Distribusi predikat di belakang subjek, posisi ini lazim terdapat dalam bahasa-bahasa bertipe SPO, termasuk bahasa Sunda. Distribusi predikat yang berposisi di depan subjek terdapat dalam klausa susun balik atau inversi dan predikat eksistif aya 'ada'.

Wujud predikat dalam bahasa Sunda dapat berwujud kata maupun frasa. Predikat yang berwujud kata yang berfungsi sebagai predikat dapat berupa kata dasar, kata berimbuhan, kata ulang, dan kata majemuk. Predikat yang berwujud frasa, dilihat dari tipe konstruksinya, frasa yang dapat berfungsi sebagai predikat, ialah frasa atributif, rasa koordinatif, dan frasa preposisional. Dari 600 data pelesapan yang terkumpul, ditemukan 102 data pelesapan predikat. Jadi hasil persentasinya adalah $17 \%$. Pelesapan predikat, bisa dilihat dari kalimat di bawah ini.

$$
\text { “A Ø sakintal." (Bari seuri) (KP2/015) }
$$$$
\text { *A [meuli daging] sakintal. }
$$

Dari kalimat di atas, unsur fungsional yang lesap yaitu predikat dan objek. Diagram pohon dari kalimat di atas sebagai berikut. 


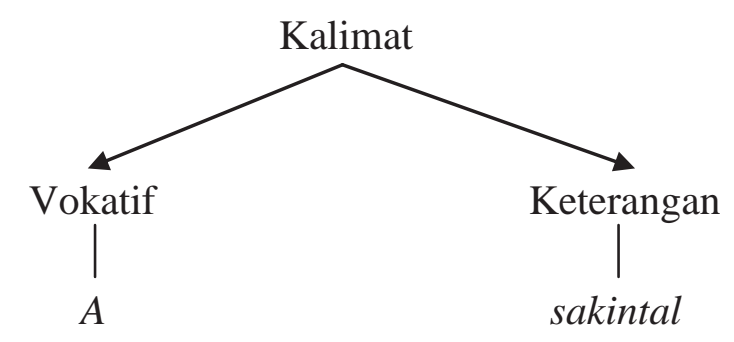

Kalimat di atas, seupama dipulangkan ke dalam kalimat dasar, mempunyai diagram pohon sebagai berikut.

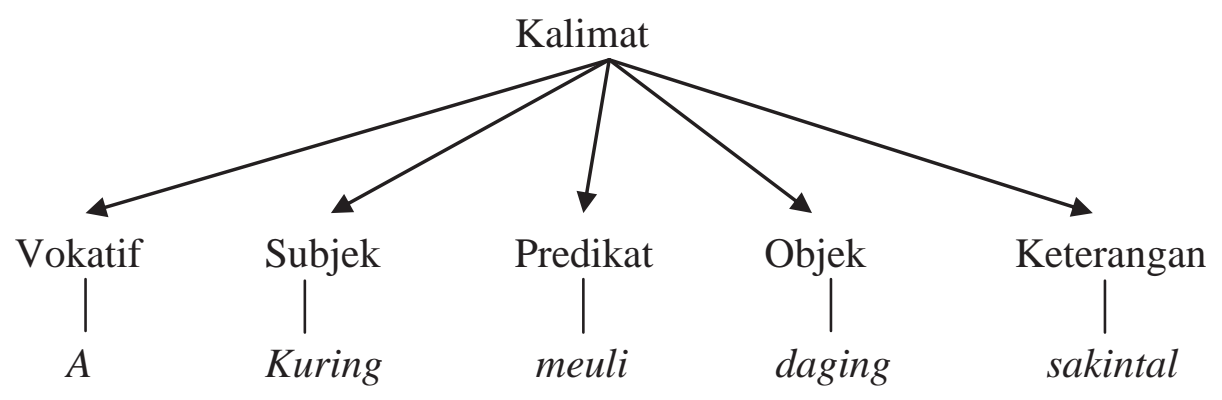

\section{3) Objek}

Objek adalah fungsi sintaksis unsur klausa yang melengkapi verba monotransitif atau verba bitransitif. Ciri objek ialah jika klausa diubah verba diatesisnya, objek akan berubah menjadi subjek. Selain mempunyai ciri, objek juga mempunyai distribusi yang cenderung berposisi di kanan atau belakang predikat-verba transitif. Diaramnya sebagai berikut.

Klausa $\rightarrow$ Subjek - Predikat - Objek (Keterangan)

Objek dalam bahasa Sunda dapat berwujud kata, frasa, maupun klausa. Objek yang berwujud kata, dapat berupa kata dasar, kata berimbuhan, kata ulang, dan kata majemuk.

Objek yang berwujud frasa, yakni frasa nominal. Dilihat dari tipenya, frasa yang berfungsi sebagai objek dapat berupa frasa atributif, frasa koordinatif, dan frasa direktif. Frasa yang berupa direktif, yakni frasa yang dibentuk dari preposisi dan nomina atau frasa nominal, preposisinya dapat dilesapkan tanpa mengubah makna klausanya. Konstruksi klausanya pun masih dapat tetap berterima.

Objek dapat berwujud klausa, yakni klausa sematan. Klausa sematan yang berfungsi sebagai objek memiliki pemarkah yang berupa konjungsi yén 'bahwa'. Dari 600 data pelesapan yang terkumpul, ditemukan 65 data pelesapan objek. Jadi hasil persentasinya adalah $10,83 \%$. Pelesapan objek, bisa dilihat dari kalimat di bawah ini.

“Ø saons, Ø saons?" (bari ngarawu bawang beureum jeung céngék).(KS/001) *[Ngagaleuh bawang beureumna] saons, [ngagaleuh céngékna] saons?

Data kalimat di atas, bawang beureum menduduki posisi sebagai objek, tapi tidak disertakan atau dilesapkan oleh pemakai bahasa (penjual), tapi tidak mempengaruhi kelancaran komunikasi, karena didukung dengan adanya bahasa nonverbal. 


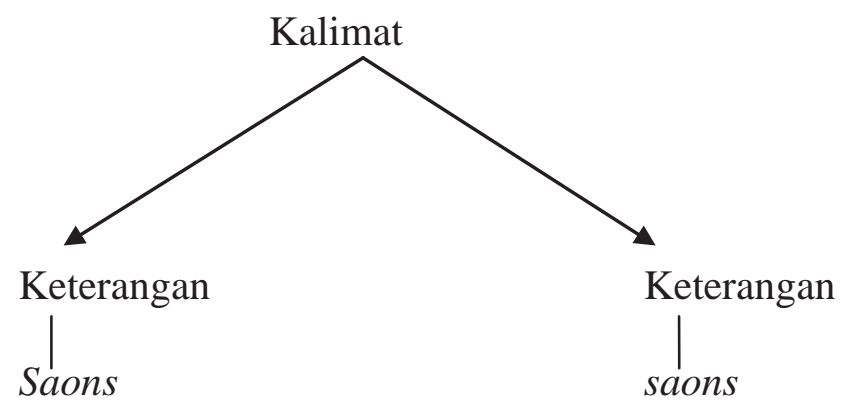

Kalimat di atas seupama dipolakan, mempunyai diagram pohon sebagai berikut.

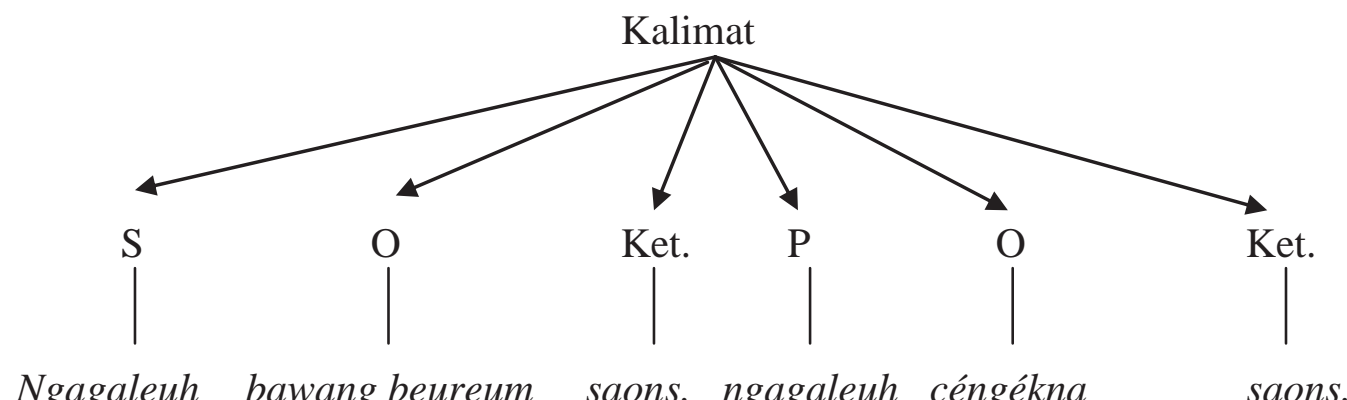

4) Pelengkap

Pelengkap adalah kata atau frasa yang secara gramatikl melengkapi kata atau frasa lain dengan menjadi subordinat padanya. Pelengkap merupakan bagian dari frasa verbal untuk membuatnya jadi predikat yang lengkap dalam klausa. Pelengkap dalam sebuah bahasa, termasuk bahasa Sunda, memiliki distribusi yang mirip dengan objek, yakni selalu terdapat di belakang predikat yang berkategori verba atau adjektiva.

Pelengkap dapat berwujud kata, frasa, maupun klausa. Pelengkap yang berwujud kata dapat berbentuk kata dasar, kata berimbuhan, kata ulang, dan kata majemuk. Pelengkap yang berwujud frasa dapat dilihat dari tipe konstruksinya, frasa yang menempati fungsi pelengkap berupa frasa objektif, frasa atributif, dan frasa direktif. Pelengkap yang berwujud klausa yakni klausa sematan. Dari 600 data pelesapan yang terkumpul, ditemukan 51 data pelesapan pelengkap. Jadi hasil persentasinya adalah $8,50 \%$. Pelesapan pelengkap, bisa dilihat dari kalimat di bawah ini.

"Cau susu, nya atuh Ø ieuna ulah

dipiceun lebar." (KC2/022)

*Cau susu, nya atuh [sikatanana] ieuna ulah dipiceun lebar.

\section{5) Keterangan}

Keterangan adalah salah satu fungsi sintaksis yang bersifat peripheral atau tambahan. Dalam klausa atau kalimat, katerangan berfungsi menerangkan predikat atau memberikan informasi tambahan tentang apa yang dijelaskan oleh predikat (Sudaryat, 2014:149). Unsur fungsional klausa yang tidak menduduki S, P, O, dan pelengkap, dapat diperkirakan menduduki fungsi keterangan. Posisi keterangan dalam klausa sangat bebas, bisa di depan, di tengah, bisa juga di belakang (Hernawan, 2007:99).

"Dua puluh Ø kamari hirupna téh, tilu kilo satengah bawaeun budak ka ditu." (KD 2/015) 
*Dua puluh [rébu rupia sakilo] kamari hirupna téh, tilu kilo satengah bawaeun budak ka ditu.

\section{SIMPULAN DAN SARAN}

Ragam bahasa lisan didukung oleh situasi pemakaian sehingga kemungkinan besar terjadi pelesapan kalimat. Namun, hal itu tidak mengurangi ciri kebakuannya. Walaupun demikian, ketepatan dalam pilihan kata dan bentuk kata serta kelengkapan unsur-unsur di dalam struktur kalimat tidak menjadi ciri kebakuan dalam ragam baku lisan karena situasi dan kondisi pembicaraan menjadi pendukung di dalam memahami makna gagasan yang disampaikan secara lisan.

Transformasi ialah proses pembentukan unsur bahasa dari struktur dasar ke struktur turunan. Transformasi yang terdapat dalam ragam bahasa lisan di masarakat pasar Padayungan mencakup kalimat transformasi tunggal yang terdiri atas (1) ingkar, (2) tanya I, (3) seruan, (4) aspek, (5) perintah, (6) kata ganti, (7) tanya II, dan (8) pemendekkan, kalimat transformasi sematan, kalimat transformasi rapatan yang terdiri atas (1) jumlah, (2) berlawanan, dan (3) kontinuatif. Transformasi fokus, dan yang terahir transformasi khusus yang terdiri dari (1) transformasi itu, dan (2) transformasi nominalisasi.

Pelesapan yang ada dalam interaksi masarakat pasar Padayungen meliputi (1) pelesapan subjek, (2) pelesapan predikat, (3) pelesapan objek, (4) pelesapan pelengkap, dan (5) pelesapan keterangan. Ada beberapa saran untuk kemajuan dunia kebahasaan dan dunia pendidikan, seperti di bawah ini:

a) perlu dilaksanakan penelitian mengenai pelesapan yang dikaitkan dengan bahan pembelajaran serta diaplikasikan pada kemampuan siwa dalam menggunakan dan menganalisis bentuk pelesapan;

b) penelitian tentang pelesapan dalam ragam bahasa lisan hanya bersumber di lingkungan pasar, dengan begitu perlu adanya penelitian lain yang meneliti bentuk pelesapan ragam bahasa lisan di tiap masarakat dan di tiap profesi atau pekerjaan.

\section{PUSTAKA RUJUKAN}

Hernawan. (2007). Pemerlengkapan dalam Bahasa Sunda. (Jurnal Sonagar JPBD FPBS UPI)

Samsuri. (1985). Tatakalimat Bahasa Indonesia. Jakarta: Sastra Hudaya.

Sudaryat, Y., dkk,. (2007). Tata Basa Sunda Kiwari. Bandung: Yrama Widya.

Sudaryat, Y. (2014). Struktur Bahasa Sunda. Bandung: Sekolah Pascasarjana UPI.

Tarigan, H.G. (2009). Pengajaran Sintaksis. Bandung: Angkasa.

\section{UCAPAN TERIMA KASIH}

Terima kasih kepada Penyunting Jurnal Lokabasa yang telah memuat tulisan ini. 